\title{
Is Teacher Professional Development an Effective Way to Mitigate Generational Digital Gap? Result from a 3-year Statewide Teacher Professional Development
}

\author{
$\mathrm{Yi} \mathrm{Li}$ \\ Correspondence: Yi Li, Faculty of Education, Southwest University; No.2 Tiansheng Road, BeiBei District, Chongqing, \\ 400715, P.R. China
}

Received: December 17, 2015

Accepted: December 31, 2015 Online Published: December 31, 2015

doi:10.11114/jets.v4i2.1253

URL: http://dx.doi.org/10.11114/jets.v4i2.1253

\begin{abstract}
This study analyzed 3-year longitudinal data (2012-2014) collected from a statewide distance professional development to examine if there was a generational digital gap between digital native and digital immigrant teachers. The study found that the digital native teachers had significantly more positive attitude and belief towards technology use in class, and they were significantly more likely to use technology for class preparation than the digital immigrant teachers before the professional development. After the professional development, the previous generational gaps were mitigated, and all the teachers improved their technology integration abilities and their technology communication and collaboration skills.
\end{abstract}

Keywords: professional development, digital naive teachers, digital immigrant teachers, differences, integration ability

\section{Theoretical Framework \& Objectives}

\subsection{Generational Digital Differences}

The concept of generational digital gap was first brought up by Prensky (2001a). Prensky (2001a) identified and labeled two demographic groups based on a level of their technological immersion: digital natives were defined as those who grew up in digital environment, and were comfortable with technology use. They witnessed a dramatic change in access to a variety of technologies throughout their growth (Frand, 2000). On the other hand, digital immigrants were defined as those who were born before digital age and they had to interact with technology later in their lives. They learnt to adapt to the new technological environment, and they retained, to some degree, their traditional habits (Prensky, 2001b). Recent empirical research has confirmed such generational differences. For example, studies indicated that digital natives used technologies more frequently and differently from their parents and teachers (Berman \& Hassell, 2014). Digital native teachers were more familiar with advanced technologies such as content creation activities than digital immigrant teachers (Kinash \& Wood, 2013). However, other researchers argued that there might not be such a distinct difference between digital native teachers and digital immigrant teachers. The digital immigrant teachers could do better than digital native teachers in using technology for purposes of teaching and learning (Ransdell, Kent, Gaillard- Kenney, \& Long, 2011).

\subsection{Statewide Online Professional Development}

The rapid evolution of new technologies influencing education in the last two decades has changed the ways teachers taught (Li, Worch, Zhou, \& Aguiton, 2015). Teachers have been tasked with the goal of integrating technology into their classrooms and curriculums in order to improve teaching quality. However, teachers were not well prepared to take on these important tasks (Salmon, 2013). In order to help teachers successfully adapt to the new environment, teachers must be provided with adequate professional development. Research has shown that high quality professional development could help improve teachers' work by helping them update their knowledge, change attitudes, and improve competency related to technology integration (Peterson \& Palmer, 2011). However, in a review of technology professional development, it was found that a significant amount of these programs were ineffective (Gemeda, Fiorucci \& Catarci, 2014). The reasons of ineffectiveness include ignoring the needs of teachers, problems with time, inappropriate instructional methods, outdated content, and lack of hands-on practice (Potter \&Rockinson-Szapkiw, 2012). 
The professional development in this study was a well-designed online training program, with the goal to mitigate generational digital gap and increase overall teachers' confidence and competence with technology integration in class. The program adopted a web-based platform that supported summer face-to-face professional development sessions, through the establishment of academic year-long online learning communities. The summer face to face professional development focused on the theory of technology integration, such as how to design, implement, and support technology integrated lessons and curricula, and modify or revise inquiry lessons to meet student and curriculum needs. The online professional development was designed to provide participants with long-term support in implementing the skills they had just acquired in classroom. The online professional development consisted of approximately twelve individual lessons. Participants were asked to develop and post lesson plans which implemented technology integrated instruction. They were then required to comment on the lesson plans posted by their peers. Some lessons also encouraged participants to review resources available for them on the Internet and discuss these resources with their peers. Communication in class was accomplished primarily through discussion boards and secondarily through e-mail. Trained facilitators monitored the online learning groups.

\section{Method}

\subsection{Research Objectives}

Three-year longitudinal data was employed to explore (1) whether there were any generational gaps regarding technology use for class preparation, student centered pedagogy, communication, and confidence level towards technology before professional development; (2) and if the differences existed, whether the professional development could successfully mitigate the generational gap; (3) how the online professional development improved overall teachers' attitudes towards technology and their technology integration ability.

\subsection{Participants}

Data was collected by an external evaluator as part of the evaluation of the teacher professional development. This study used the recent data (2012-2014) to reflect the current situation of digital native teachers and digital immigrant teachers' technology use behaviors. The sample included regular mathematics and science teachers, and also special education, resource, or inclusion teachers who taught at least one regularly scheduled class in grades K-12. Excluded from the sampling were teachers' assistants, school or district administrators, supervisors, and counselors. The overall teachers were categorized into three groups based on the length of teaching experience: young digital native group (1 to 5 years), mature digital native group (6 to 15 years), and digital immigrant group (more than 15 years). Descriptive statistics for the three groups of teachers were presented in Table 1 . There were 195 younger digital native teachers, 1104 mature digital native teachers, and 675 digital immigrant teachers (Table 1).

Table 1. Demographic information for digital native and digital immigrant teachers

\begin{tabular}{|c|c|c|c|}
\hline (2) & $\begin{array}{l}\text { Young } \\
\text { digital natives } \\
\mathrm{n}=195\end{array}$ & $\begin{array}{l}\text { Mature } \\
\text { digital natives } \\
\mathrm{n}=1104\end{array}$ & $\begin{array}{l}\text { Digital } \\
\text { immigrants } \\
\mathrm{n}=675\end{array}$ \\
\hline \multicolumn{4}{|l|}{ Year $(\%)$} \\
\hline 2012 & 41.03 & 36.92 & 22.05 \\
\hline 2013 & 36.98 & 35.08 & 27.94 \\
\hline 2014 & 31.41 & 35.41 & 33.19 \\
\hline \multicolumn{4}{|l|}{ Gender $(\%)$} \\
\hline Male & 10.31 & 13.99 & 13.48 \\
\hline Female & 89.69 & 86.01 & 86.52 \\
\hline \multicolumn{4}{|l|}{ Ethnicity (\%) } \\
\hline Caucasian & 98.46 & 95.84 & 97.17 \\
\hline African American & 1.03 & 1.90 & 1.49 \\
\hline Hispanic & 0.51 & 1.27 & 0.45 \\
\hline Asian & 0 & 0.45 & 0.30 \\
\hline American Indian & 0 & 0.09 & 0 \\
\hline Other & 0 & 0.45 & 0.60 \\
\hline \multicolumn{4}{|l|}{ Teaching grade $(\%)$} \\
\hline Elementary school & 73.85 & 74.3 & 74.37 \\
\hline Middle school & 10.77 & 11.22 & 9.24 \\
\hline High school & 15.39 & 14.48 & 15.94 \\
\hline \multicolumn{4}{|l|}{ School type (\%) } \\
\hline Public School District & 96.92 & 98.64 & 98.96 \\
\hline Nonpublic School & 1.54 & 0.73 & 0.89 \\
\hline Other Institution & 1.54 & 0.64 & 0.15 \\
\hline \multicolumn{4}{|l|}{ Teaching subject (\%) } \\
\hline Self-contained class ${ }^{1}$ & 50.77 & 45.43 & 46.74 \\
\hline Math and Science & 5.64 & 8.42 & 7.12 \\
\hline Math only & 13.85 & 13.48 & 12.17 \\
\hline Science only & 8.72 & 13.76 & 12.17 \\
\hline Other or multi-subject combinations & 21.03 & 18.91 & 21.81 \\
\hline
\end{tabular}

${ }^{1}$ Teach all or most academic subjects to one class 


\subsection{Measures}

A self-report pre- and a post- questionnaire were used for this study. The pre- and post-questionnaire were tested in pilot studies and revised accordingly to ensure their appropriate psychometric properties. Participants completed the questionnaires as part of their first and final assignments for the program across one academic year. Unique identifiers were used to link participants' pre- and post-questionnaire responses. The data was repeatedly collected for consecutive three years. In addition to providing their demographic information, participants reported their attitude and belief towards technology, behaviors of technology uses for class preparation, student centered pedagogy, and communication and collaboration. Items used for measuring the four constructs were rated on a five-point Likert scale, ranging from 1 -strongly disagree to 5-strongly agree. Reliability of each construct to its subscales was examined by Cronbach's alpha. As shown in Table 2, all the factors have relatively a good reliability, except use of technology for communication and collaboration (Alpha $=0.60$ ). This was probably due to the construct being measured only by two items. Quantitative data were analyzed using descriptive statistics, frequency and independent $t$-test, and Bonferroni multiple comparisons to examine how the digital immigrant teachers differed from the digital native teachers before and after the professional development.

Table 2. Factors and measures

\begin{tabular}{|c|c|}
\hline Factors & Measures \\
\hline \multirow{4}{*}{$\begin{array}{l}\text { Attitude and belief } \\
\text { towards technology } \\
(\text { Alpha=0.87) }\end{array}$} & I am comfortable using technology to learn. \\
\hline & I am comfortable using the Web to learn and teach. \\
\hline & I value Web-based professional development. \\
\hline & I have a good understanding of how to use technology effectively in the classroom. \\
\hline \multirow{4}{*}{$\begin{array}{l}\text { Use of technology for } \\
\text { preparation (Alpha }=0.85 \text { ) }\end{array}$} & Use the Internet to find lesson plans. \\
\hline & Use the Internet to find content references to enhance my lesson. \\
\hline & Use the Internet to find resources to help me teach topics that I am less prepared to teach. \\
\hline & Use the Internet to find appropriate content references for others (e.g., parents, guardians, tutors, etc.) \\
\hline \multirow{4}{*}{$\begin{array}{l}\text { Technology involved } \\
\text { teaching pedagogy } \\
\text { (Alpha=0.85) }\end{array}$} & Assist students in using Web-based resources. \\
\hline & Have my students use the Internet for interactive simulations or activities. \\
\hline & Have my students use the Internet to find sources of information when conducting research. \\
\hline & Have my students use technology to reinforce or review concepts discusses in class. \\
\hline \multirow{2}{*}{$\begin{array}{l}\text { Use of technology for } \\
\text { communication and } \\
\text { collaboration (Alpha }=0.60 \text { ) }\end{array}$} & Participate in on-line chats with other teachers about a teaching issue or idea. \\
\hline & $\begin{array}{l}\text { Use the Internet to communicate with teachers and/or administrators about professional and } \\
\text { instructional issues. }\end{array}$ \\
\hline
\end{tabular}

\section{Results}

As shown in Table 3, generational differences were detected in terms of attitude and belief towards technology and use of technology for preparation. Young digital native teachers had significantly more positive attitude and belief towards technology than mature digital native teachers and digital immigrant teachers. Similarly, the mature digital native teachers had significantly more positive attitude and belief towards technology than the digital immigrant teachers. In addition, the mature digital native teachers were significantly more likely to use technology for class preparation than the immigrant teachers. All these differences were diminished after the teachers participated in the professional development.

Technology involved student centered pedagogy and teachers' use of technology for communication and collaboration did not differ between teachers with different years of teaching experience. This was probably because the digital native teachers lacked teaching strategy or classroom management skills compared with the digital immigrant teachers. Like the digital immigrant teachers, the digital native teachers were not taught with much technology during their K-12 schooling by their teachers. Thus, digital native teachers did not have much experience with subject-specific technologies and communication skills with technologies as well as digital immigrant teachers. Researchers have pointed out digital native teachers mainly used technologies for their personal interests outside of the classroom (Johnson, Adams Becker, Estrada\& Freeman, 2014).

After the professional development, means of teachers' attitude and belief towards technology, their use of technology for class preparation, technology involved student centered pedagogy, and technology communication and collaboration skills were significantly improved for both digital native and digital immigrant teachers. 
Table 3. Differences among younger digital native (YNA) ( $n=195)$, mature digital native (MNA) $(n=1106)$, and digital immigrant (IM) teachers $(n=675$ )

\begin{tabular}{|c|c|c|c|c|c|c|c|c|c|c|c|}
\hline & \multicolumn{4}{|c|}{ Pre professional development } & \multicolumn{4}{|c|}{ Post professional development } & \multicolumn{3}{|c|}{ Pre-post comparisons } \\
\hline & YNA & $\begin{array}{l}\text { MNA } \\
\text { Mean (SL }\end{array}$ & IM & $\begin{array}{l}\text { Group } \\
\text { Bonferroni } \\
\text { comparison }\end{array}$ & YNA & MNA & IM & $\begin{array}{l}\text { Group } \\
\text { Bonferroni } \\
\text { comparison }\end{array}$ & YNA & $\begin{array}{l}\text { MNA } \\
\text { ffect size }\end{array}$ & IM \\
\hline $\begin{array}{l}\text { Attitude and belief } \\
\text { towards technology }\end{array}$ & $\begin{array}{l}4.22 \\
(.57)\end{array}$ & $\begin{array}{l}4.12 \\
(.59)\end{array}$ & $\begin{array}{l}4.01 \\
(.64)\end{array}$ & $\begin{array}{l}.000^{* * *} \\
\text { YNA-IM*** } \\
\text { MNA-IM**** }\end{array}$ & $\begin{array}{l}4.18 \\
(.54)\end{array}$ & $\begin{array}{l}4.18 \\
(.58)\end{array}$ & $\begin{array}{l}4.19 \\
(.57)\end{array}$ & .970 & -.07 & $.11 * * *$ & $.29 * * *$ \\
\hline $\begin{array}{l}\text { Use of technology for } \\
\text { preparation }\end{array}$ & $\begin{array}{l}3.72 \\
(.73)\end{array}$ & $\begin{array}{l}3.70 \\
(.78)\end{array}$ & $\begin{array}{l}3.60 \\
(.81)\end{array}$ & $\begin{array}{l}.036^{*} \\
\text { MNA-IM* }\end{array}$ & $\begin{array}{l}3.77 \\
(.75)\end{array}$ & $\begin{array}{l}3.79 \\
(.76)\end{array}$ & $\begin{array}{l}3.72 \\
(.78)\end{array}$ & .184 & .07 & $.12 * * *$ & $.14 * * *$ \\
\hline $\begin{array}{l}\text { Technology involved } \\
\text { student centered } \\
\text { pedagogy }\end{array}$ & $\begin{array}{l}3.35 \\
(.77)\end{array}$ & $\begin{array}{l}3.26 \\
(.83)\end{array}$ & $\begin{array}{l}3.25 \\
(.83)\end{array}$ & .312 & $\begin{array}{l}3.36 \\
(.80)\end{array}$ & $\begin{array}{l}3.33 \\
(.83)\end{array}$ & $\begin{array}{l}3.36 \\
(.82)\end{array}$ & .592 & .02 & $.08 * *$ & $.14 * * *$ \\
\hline $\begin{array}{l}\text { Use of technology for } \\
\text { communication and } \\
\text { collaboration }\end{array}$ & $\begin{array}{l}2.94 \\
(1.04)\end{array}$ & $\begin{array}{l}2.90 \\
(1.02)\end{array}$ & $\begin{array}{l}2.85 \\
(1.06)\end{array}$ & .508 & $\begin{array}{l}3.39 \\
(.91)\end{array}$ & $\begin{array}{l}3.32 \\
(.99)\end{array}$ & $\begin{array}{l}3.34 \\
(1.03)\end{array}$ & .591 & $.47 * * *$ & $.42 * * *$ & $.47 * * *$ \\
\hline
\end{tabular}

Note: $* p<0.05, * * p<0.01, * * * p<0.001$

\section{Discussions and Implications}

The digital native teachers were more comfortable and felt more confident in using technology than the digital immigrant teachers. The digital native teachers also more frequently used technology for class preparation. However, the digital native teachers did not more frequently use technology for student centered pedagogy and for communication and collaboration. The reserved behaviors, on one hand, showed that they understood it was a complex process to make technologies facilitate teaching effectively, but on the other hand, revealed that despite the greater comfort with technology as a whole, digital natives still needed training for teaching-specific technologies to help improve their pedagogy so that they can integrate technology in their teaching effectively. As for digital immigrant teachers, they had more teaching experience but may lack basic technology operation skills. Thus, future training could shift more emphasis on technology operational knowledge for them.

In addition, the online professional development was successful. It did not only mitigate the existing generational gap, but also increased the both groups of teachers' abilities to integrate technology with their teaching. The reasons why this program was so successful needs deep reflection. The professional development utilized an online platform, thus participants had the flexibility to learn and participate at their own pace (Chuang \& Tsai, 2005). Given the increase in fast paced lifestyles, more people view web-based learning environments as a more practical option (O'Donoghue et al., 2001). Also, this technology training program did not only train teachers to use technology itself, rather focused on connecting technology with their teachings, such as teachers being taught how to design and implement lessons and curricula supported by technology, and also taught how to modify or revise inquiry lessons to meet participants' individual needs. Previous literature has showed that professional development could have effects on improving teachers' technology integration ability, only if teachers were taught to understand the interwoven relationships of subject content, pedagogy, technology and how these aspects worked together (Kajijevich, 2012). Lastly, the online professional development was designed to provide participants with long-term support in implementing the skills they had just acquired in class. This finding resonates with the most recurring models of successful professional development in the literature as an ongoing supportive environment or collaborative learning group (Thota \& Negreiros, 2015).

\section{Conclusions}

This study analyzed the longitudinal empirical data, and found that digital native teachers were significantly more likely to use technology for class preparation and they had more positive belief towards technology than digital immigrant teachers originally. After the professional development, no significant differences between them were detected. The findings of this study provided evidence that the generational differences did exist, but such differences could be moderated by a well-designed professional development. The findings of this research recommended that future professional development could consider the existing disparities between teachers, and provided digital immigrant teachers with more basic technology operational skills and promoted their attitude and belief towards technology use in teaching. In addition, professional development could help digital native as well as immigrant teachers integrate technology into teaching in meaningful ways, if the professional development focuses on helping teachers designing new curriculums, improving technological teaching strategies, and technological communication skills, rather than teaching technology as a separate and independent domain.

\section{Limitation}

One limitation of this study was that it only involved data from one state professional development program. Should a similar future study be conducted, it would need to synthesize findings from more professional development. In 
addition, it was acknowledged that there were limitations in categorizing digital native and immigrant teachers only based on years of teaching in this study. For example, a teacher with little teaching experience could possibly be a mature person and born before the digital age. According to Prensky (2001a), the cut-off standard to categorize digital natives and digital immigrants was year of born. Recently, researchers argued that it was not reasonable to paint a monolithic portrait of the young generation as technologically savvy and technologically enthusiastic, while the old generation as technologically impaired and a technology opponent. The large variation with the digital native and the digital immigrant generation called for more studies to study other factors, other than teaching experience or year of born, to paint the distinctive portraits of digital native versus digital immigrants.

\section{Acknowledgements}

The research is supported by the Chongqing Federation Social Science Plan Funds (2014BS120).

\section{References}

Berman, R., \& Hassell, D. (2014).Digital native and digital immigrant use of scholarly network for doctoral learners. Journal of Educators Online, 11(1), 1-26.

Chuang, S. C., \& Tsai, C. C. (2005). Preferences toward the constructivist Internet-based learning environments among high school students in Taiwan. Computers in Human Behavior, 21, 255-272. http://dx.doi.org/10.1016/j.chb.2004.02.015

Frand, J. (2000). The information-age mindset: Changes in students and implications for higher education. EDUCAUSE Review, September-October, 15-24.

Gemeda, F. T., Fiorucci, M., \& Catarci, M. (2014). Teachers' professional development in schools: Rhetoric versus reality, Professional Development in Education, 40(1), 71-88. http://dx.doi.org/10.1080/19415257.2012.759988

Johnson, L., Adams Becker, S., Estrada, V., \& Freeman, A. (2014). NMC Horizon Report: 2014 K-12 Edition. Austin, TX: New Media Consortium.

Kajijevich, D. M. (2012). TPCK framework: assessing teachers' knowledge and designing courses for their professional development. British Journal of Educational Technology, 43(1), 28-30. http://dx.doi.org/10.1111/j.1467-8535.2011.01246.x

Kinash, S., \& Wood, K. (2013). Academic developer identity: How we know who we are, International Journal for Academic Development, 18(2), 178-189. http://dx.doi.org/10.1080/1360144X.2011.631741

Li, L., Worch, E., Zhou, Y. C., \& Aguiton, R. (2015). How and why digital generation teachers use technology in the classroom: An explanatory sequential mixed methods study. International Journal for the Scholarship of Teaching and Learning, 9(2), 9.

O'Donoghue, J., Singh, G., \& Dorward, 1. (2001). Virtual education in universities: a technological imperative. British Journal of Educational Technology, 32, 511-523. http://dx.doi.org/10.1111/1467-8535.00221

Peterson, S., \& Palmer, L. B. (2011). Technology confidence, competence, and problems solving strategies: Differences within online and face-to-face formats. International Journal of E-Learning \& Distance Education, 25(2).

Potter, S. L., \& Rockinson-Szapkiw, A. J. (2012). Technology integration for instructional improvement: The impact of professional development. Performance Improvement, 51(2), 22-27. http://dx.doi.org/10.1002/pfi.21246

Prensky, M. (2001a). Digital natives, digital immigrants. On the Horizon, 9(5), 1-6. http://dx.doi.org/10.1108/10748120110424816

Prensky, M. (2001b). Digital natives, digital immigrants, part II: Do they really think differently? On the Horizon, 9(6), 1-6. http://dx.doi.org/10.1108/10748120110424843

Ransdell, S., Kent, B., Gaillard-Kenney, S., \& Long, J. (2011). Digital immigrants fare better than digital natives due to social reliance. British Journal of Educational Technology, 42(6), 931-938. http://dx.doi.org/10.1111/j.1467-8535.2010.01137.x

Salmon, A. (2013). Exploring professional development needs of digital immigrants and digital native teachers for the successful integration of technology in a Jewish elementary school setting. Unpublished doctoral dissertation, Northeastern University, Illinois.

Thota, N., \& Negreiros, J. G. M. (2015). Introducing educational technologies to teachers: Experience report. Journal of University Teaching \& Learning Practice, 12(1), 1-13.

\section{$(\mathrm{Cc}) \mathrm{BY}$}

This work is licensed under a Creative Commons Attribution 3.0 License. 